\title{
Mean Platelet Volume Values May Have not a Predictive Role for the Presence of Nephritis in Systemic Lupus Erythematosus Patients
}

\author{
Cengiz BEYAN, ${ }^{1}$ Esin BEYAN ${ }^{2}$ \\ ${ }^{1}$ Department of Internal Medicine, TOBB University of Economics and Technology, Faculty of Medicine, Ankara, Turkey \\ ${ }^{2}$ Department of Internal Medicine, Keçioren Training and Research Hospital, Ankara, Turkey
}

Dear Editor,

We read with a great interest the research article of Ayna et al. ${ }^{1}$ about mean platelet volume (MPV) values in patients with lupus nephritis. They suggested that MPV values might be discriminating for lupus nephritis. We would like to comment on the results of this study.

Although MPV can be easily obtained with automated blood counters, the measurement of this parameter still has no standardization. ${ }^{2}$ Jackson and Carter $^{3}$ had reviewed the variables affecting the values of MPV including time of analysis after venepuncture. Ethylenediaminetetraacetic acid, the most commonly used anticoagulant, causes time dependent platelet shape changes. Maximal variation occurs within the first two hours after venepuncture. Generally, the MPV multiplies up to $30 \%$ within five minutes of exposure to ethylenediaminetetraacetic acid and increases additionally $10-15 \%$ over the subsequent two hours. ${ }^{3}$ On the other hand, the MPV values vary being instrument-specific. With a meta-analysis, Beyan and Beyan ${ }^{4}$ showed that the measurement times between 15 minutes and two hours were significantly different from the measurement times shorter than 15 minutes and longer than two hours. Also, they found that the MPV values measured with Sysmex (Sysmex Corporation, Kobe, Japan) were significantly higher than the MPV values measured with Beckman Coulter
(Beckman Coulter Inc., Fullerton, California, USA), Abbott CELL-DYN (Abbott Laboratories, Abbott Park Road, Illinois, USA), and Siemens ADVIA (Siemens Healthcare $\mathrm{GmbH}$, Erlangen, Germany). The MPV measurements varied up to $17.8 \%$ by the instruments and maximum deviation together with the difference of instruments used plus MPV measurement times was up to $27.7 \% .4$ Preanalytic variabilities like measurement time cannot be ignored becau se these factors affect the results considerably. Therefore, the MPV studies should be performed prospectively. The data of the study of Ayna et al. ${ }^{1}$ were obtained retrospectively from the files of the patients between January 2000 and June 2015. Because the measurement times after venepuncture and used instruments for blood counting were not known in this study, the data reliability was questionable. Actually, it is widely accepted that MPV has presently no role in establishing diagnosis and defining prognosis in any acquired illness. $^{2}$

As a result, MPV values may not have a predictive role for the presence of nephritis in patients with systemic lupus erythematosus.

\section{Declaration of conflicting interests}

The authors declared no conflicts of interest with respect to the authorship and/or publication of this article.

Received: February 01, 2017 Accepted: February 27, 2017 Published online: May 08, 2017

Correspondence: Cengiz Beyan, MD. TOBB Ekonomi ve Teknoloji Üniversitesi Tıp Fakültesi İç Hastalıkları Anabilim Dalı, 06560 Söğütözü, Ankara, Turkey.

Tel: +90 312 - 2929832 e-mail: cengizbeyan@hotmail.com

○2017 Turkish League Against Rheumatism. All rights reserved. 


\section{Funding}

The authors received no financial support for the research and/or authorship of this article.

\section{REFERENCES}

1. Ayna AB, Ermurat S, Coşkun BN, Harman H, Pehlivan Y. Neutrophil to lymphocyte ratio and mean platelet volume as inflammatory indicators in systemic lupus erythematosus nephritis. Arch Rheumatol 2017;32:21-5.

2. Noris P, Melazzini F, Balduini CL. New roles for mean platelet volume measurement in the clinical practice? Platelets 2016;27:607-12.

3. Jackson SR, Carter JM. Platelet volume: laboratory measurement and clinical application. Blood Rev 1993;7:104-13.

4. Beyan C, Beyan E. Were the measurements standardized sufficiently in published studies about mean platelet volume? Blood Coagul Fibrinolysis 2017;28:234-6.

\section{Author Reply}

Dear Editor

We read with interest the correspondence to our article regarding the "Neutrophil to lymphocyte ratio and mean platelet volume as inflammatory indicators in systemic lupus erythematosus nephritis". We thank the authors for their interest in our article.

We agree about the variables affecting mean platelet volume. In our center, total blood count evaluation is performed with impedance, optic laser scatter, and radio frequency method and all complete blood count samples are collected in standard ethylenediaminetetraacetic acid tubes and analyzed within 30 minutes with the same analyzer device.

Platelet activation is associated with the pathophysiology of diseases prone to thrombosis and inflammation. ${ }^{1}$ As in our study conclusion, further prospective studies are needed in this area.

\section{REFERENCE}

1. Gasparyan AY, Ayvazyan L, Mikhailidis DP, Kitas GD. Mean platelet volume: a link between thrombosis and inflammation? Curr Pharm Des 2011;17:47-58.

Correspondence: Ata Bora Ayna, MD. Uludağ Üniversitesi Tıp Fakültesi Fiziksel Tip ve Rehabilitasyon Anabilim Dalı, Romatoloji Bilim Dalı, 16059 Görükle, Bursa, Turkey.

Tel: +90 224 - 2962630 e-mail: asklepios80@windowslive.com 